\title{
Structure of epidermis wall, cuticle and cuticular microcracks in nectarine fruit
}

\author{
C Nguyen-the \\ Institut National de la Recherche Agronomique, Station de Technologie des Produits Végétaux, \\ Domaine St-Paul, BP 91, 84143 Montfavet Cedex, France
}

(Received 12 July 1991; accepted 5 October 1991)

\begin{abstract}
Summary - The fine structure of the epidermis of the nectarine fruit ("Tasty-fruit" cultivar) has been investigated. The work was mainly focussed on cuticular microcracks which occur on the ripe fruit. The outer wall of the epidermal cell is thick and is composed of different layers which exhibit various textures. A layer that could be interpreted as a cutinized, dense network of polysaccharidic fibrils, clearly appears at the junction between the cuticle and the wall. Cracks result in an abrupt interruption of the cuticle, but the layer at the junction of the cuticle and the wall and in some instances the waxes remain at the surface of the cell wall. The wall itself shows the same aspect in the cracks and under the normal cuticle. The susceptibility of cracks to the penetration by phytopathogenic fungi is discussed.
\end{abstract}

nectarine / cuticle / cell-wall / epidermis

Résumé - Structure de microfissures cuticulaires dans la paroi épidermique de nectarine. La structure fine de l'épiderme de nectarine (cultivar "Tasty-fruit") a été étudiée en microscopie optique et en microscopie électronique à transmission. Le travail a été principalement orienté sur des microfissures cuticulaires qui surviennent sur les fruits mûrs. En microscopie optique (fig 1-4) les microfissures sont nettement visibles et paraissent limitées à la couche cuticulaire, sans prolongement dans la paroi épidermique. En microscopie électronique, la paroi externe des cellules épidermiques apparaît épaisse et constituée de plusieurs couches (fig 5). À la jonction entre la paroi et la cuticule, une couche formée d'un réseau de microfibrilles polysaccharidiques enrobées dans une matrice opaque d'origine cuticulaire est clairement visible (fig 6). Les fissures se traduisent par une interruption brutale de la cuticule (fig 10-11), mais la paroi présente le même aspect dans les fissures et sous la cuticule normale. La couche constituant la jonction entre la paroi et la cuticule, et dans certains cas des cires, subsistent à la surface de la paroi cellulaire (fig 12). Dans les fissures s'étendant sur plusieurs cellules épidermiques, des crevasses profondes ont été observées à la jonction entre 2 cellules adjacentes (fig 14) bien que plus généralement l'interface entre cellules semble renforcée par une structure cuticulaire (fig 15). La texture de la paroi épidermique (c'est-à-dire la disposition des fibrilles de cellulose) a été étudiée sur des échantillons traités par la méthylamine afin d'extraire la matrice amorphe de la paroi. La paroi externe des cellules épidermiques est constituée de couches de textures variées (fig 17-24). La texture des parois situées sous la cuticule normale ne paraît pas différente de celle des parois situées sous les fissures cuticulaires. La sensibilité des fissures à la pénétration par des champignons phytopathogènes est discutée.

nectarine / cuticule / paroi cellulaire / épiderme

\section{INTRODUCTION}

The fungal penetration of the epidermis of plants generally involves the degradation of cuticle by cutinolytic enzymes (Kolattukudy and Koller, 1983). Spontaneous microcracks have been noticed in the cuticle of many fruits - apple (Mourichon and Bompeix, 1979), grape
(Bessis, 1972), nectarine (Fogle and Faust, 1975 and 1976) - and could play an important role in the penetration of fungal pathogens.

On mature nectarine fruits, scanning electron microscope investigations have shown that, in some instances, the fungal pathogens Monilia laxa (Aderh and Ruhl) Honey and Rhizopus stolonifer (Ehren B ex Fr) Lind obviously pene- 
trate through cuticular microcracks (Nguyen-the et al, 1989). Direct penetration through an intact cuticle has never been observed and cuticular microcracks are therefore likely to play a major role in the penetration of fungal pathogens in nectarine fruit. However, in most cases neither $M$ laxa nor $R$ stolonifer exhibit any attraction toward these microcracks (Nguyen-the et al, 1989). Healing processes of artificial lesions together with suberin and lignin synthesis has been demonstrated in the case of tomato fruit (Dean and Kolattukudy, 1976; Fleuriet and Deloire, 1982) but little is known about spontaneous cracking of the epidermis.

An investigation of the fine structure of nectarine fruit epidermis and especially of cuticular microcracks, was therefore necessary for a better understanding of the penetration mechanisms of fungal pathogens.

\section{MATERIALS AND METHODS}

\section{Biological material}

Nectarine fruits from the "Tasty-fruit" cultivar were obtained from an Institut National de la Recherche Agronomique orchard in the south-east of France. Fruits were picked at a fully ripe state of maturity. Small pieces of the epidermis were cut with a razor blade in an area close to the stylar end of the fruit. The presence of microcracks was checked using a stereomicroscope. Samples were collected from 3 fruits. Some samples were dipped $10 \mathrm{~min}$ in chloroform to remove waxes before the fixation procedure.

\section{Specimen preparation for electron and light microscopy}

Both dewaxed and untreated samples were prepared for examination with an electron microscope according to the procedure described by Roland (1978). Pieces of epidermis were fixed for $1 \mathrm{~h} 30 \mathrm{~min}$ in glutaraldehyde ( $4 \%$ in a caccodylate buffer $0.1 \mathrm{M}, \mathrm{pH} 7.4$ ) under vacuum and rinsed in the cacodylate buffer. Some samples were then either post-fixed in $\mathrm{OsO}_{4}$ $\left(1 \%\right.$ in $\mathrm{H}_{2} \mathrm{O}$ ) for $1 \mathrm{~h}$ or placed for one night in a methylamine solution $\left(40 \%\right.$ in $\left.\mathrm{H}_{2} \mathrm{O}\right)$ on a rotary shaker to remove part of the matrix and to expose the wall texture (Reis, 1981-1982). All samples were dehydrated and embedded in a mixture of Epon and Araldite resins (Araldite $4 \mathrm{ml}$, Epon $5 \mathrm{ml}$, hardener DDSA $12 \mathrm{ml}$, accelerator DMP30 $0.6 \mathrm{ml}$, Fluka). Infiltration was ex- tended (up to 3 days) to ensure penetration of the resins through the cuticle and the thick walls of the epidermis. Three sets of samples were eventually obtained:

- samples fixed with aldehyde and $\mathrm{OsO}_{4}$;

- samples fixed with aldehyde only and extracted with methylamine;

- samples dewaxed and fixed with aldehyde and $\mathrm{OsO}_{4}$.

\section{Staining and observations}

For general morphological observation under light microscopy, thick sections were directly stained with toluidine blue. For histochemical observations, sections were treated according to Maxwell (1978) in order to remove resins. They were subsequently stained with Sudan red, or with colloidal iron-potassium cyanoferrate staining, using a commercial solution of dialysed iron ( $5 \% \mathrm{Fe}_{2} \mathrm{O}_{3}, \mathrm{BDH}$ ), according to Martoja and Martoja-Pierson (1967). Stained sections were mounted in Eukitt and observed with a Zeiss microscope, except those sections stained with Sudan red which were mounted in water for the observation.

For electron microscopic observation, thin sections were treated according to PATAg reaction (periodic acid, thiosemicarbazide, silver) (Thiery, 1967; Roland, 1978) to contrast polysaccharides. Sections were collected and transferred to the different reagents with plastic rings, then deposited on copper grids. The specificity of periodic oxidation was controlled by substituting $\mathrm{H}_{2} \mathrm{O}_{2}$ (10\% in $\mathrm{H}_{2} \mathrm{O}$ for $25 \mathrm{~min}$ ) for periodic acid. Sections were observed with a Philips 300 or a Philips 400 electron microscope.

\section{RESULTS}

\section{General morphology}

The epidermis of ripe nectarine fruit consists of a single layer of irregularly shaped cells with thick walls, covered with a cuticle (fig 1). Hypodermis cells appear flat, with thinner walls.

Cell walls are stained purple or pink by toluidine blue, whereas the cuticle exhibits a more bluish color. A dark purple layer is visible at the junction between the cuticle and the wall of epidermal cells (figs 1,2). Cuticular pegs are frequently observed in the anticlinal walls of epidermal cells.

After the colloidal iron-cyanoferrate staining, cell walls are coloured in blue (fig 3 ) but on the 
cuticle the dye remains yellow. The interpenetration of cuticular pegs with walls of epidermal cells is therefore clearly visible, but the junction layer, which contrasts well in sections stained with toluidine blue, does not appear.

\section{Different layers in the outer wall and cuticle of the epidermal cell}

In spite of many variations, the outer wall of the epidermal cell frequently exhibits 2 distinct layers (fig 5). The inner layer (l) shows a dense pattern of silver granules and is composed of many "lacuna-like" regions. The median layer (II), is only lightly contrasted and seems to merge gradually with the dense material of the layer at the junction of the cuticle (jl). The latter exhibits a dense reticulate structure rich in silver granules, together with a dark amorphous matrix (fig 6).

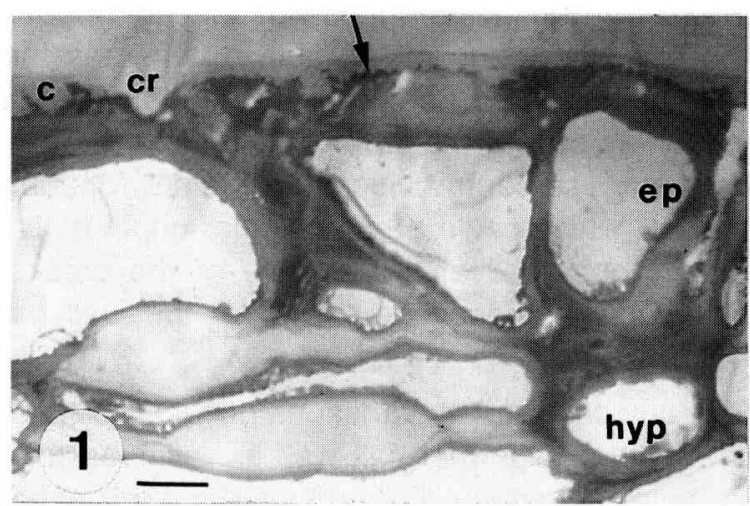

Fig 1. General view of nectarine fruit epidermis. Toluidine blue. Note the dark layer at the junction between cuticle and wall and the cuticular pegs in the anticlinal wall of adjacent cells (*). Abbreviations and symbols common to all figures : $c$ : cuticle; $\mathrm{cr}$ : cracks; ep : epidermis; hyp : hypodermis; $-: 5 \mu \mathrm{m}$.

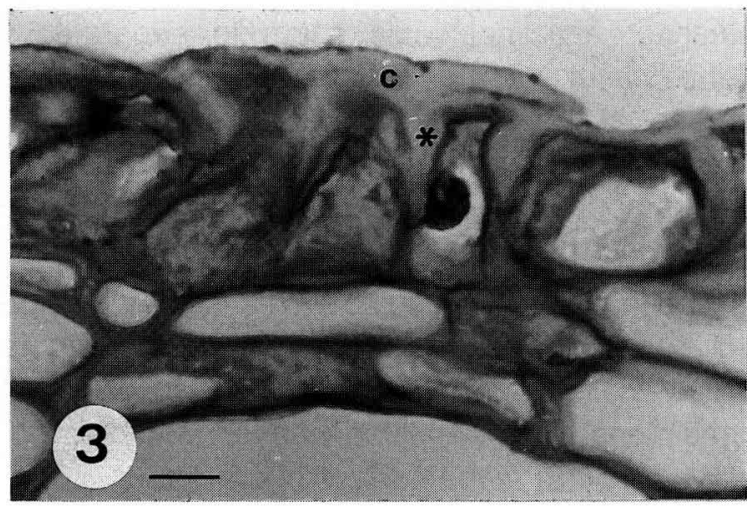

Fig 3. General view of nectarine fruit epidermis. Ironcyanoferrate/colloidal iron. Cuticle were stained yellow and cell walls blue. Cuticular pegs were clearly contrasted (*). Abbreviations as in figure 1 .
Cuticular materials are poorly contrasted (fig 5) but a reticulate network of fibrils is visible in the internal part of the cuticle $(\mathrm{rl})$ and seems to be continuous with the junction layer. The external part of the cuticle is amorphous (al). The outermost layer, which presumably consists of waxes (w), appears electron-translucent and is merely limited by an electron-opaque deposit. This layer is not visible in sections performed on dewaxed samples (fig 7) and is probably removed by the chlorofom extraction. In this picture, the wall exhibits a very compact structure, without lacunae or median layer.

In sections contrasted after oxidation with $\mathrm{H}_{2} \mathrm{O}_{2}$ instead of periodic acid, cell walls appear electron-translucent whereas an amorphous, opaque layer is visible between the cuticle and the wall (ji) (fig 8 ). The reticulate pattern of silver deposits in (ji) described above (fig 6) is not visible. On the contrary, a translucent pattern which

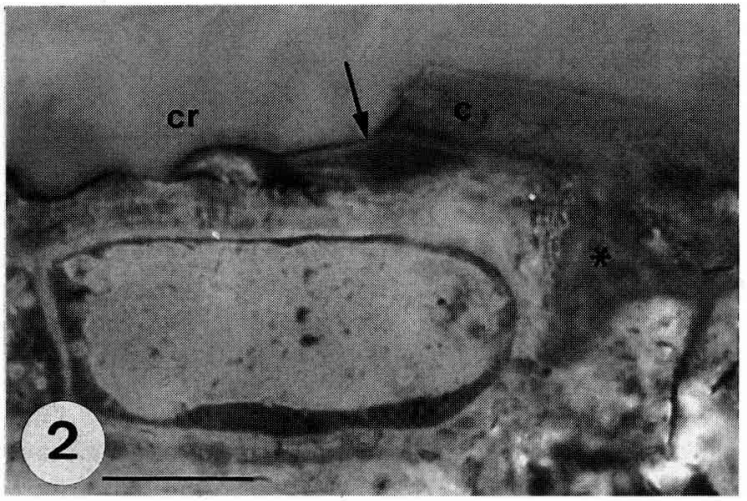

Fig 2. General view of nectarine fruit epidermis. Toluidine blue. Note the dark layer at the junction between cuticle and wall and the cuticular pegs in the anticlinal wall of adjacent cells $\left(^{*}\right)$. Abbreviations as in figure 1 .

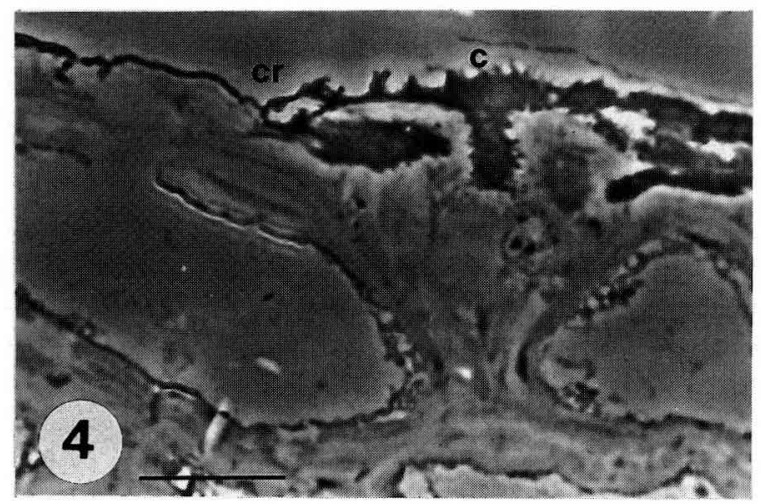

Fig 4. General view of nectarine fruit epidermis. Sudan red. Section observed under phase contrast. The inner part of cuticle was coloured in red. Abbreviations as in figure 1. 


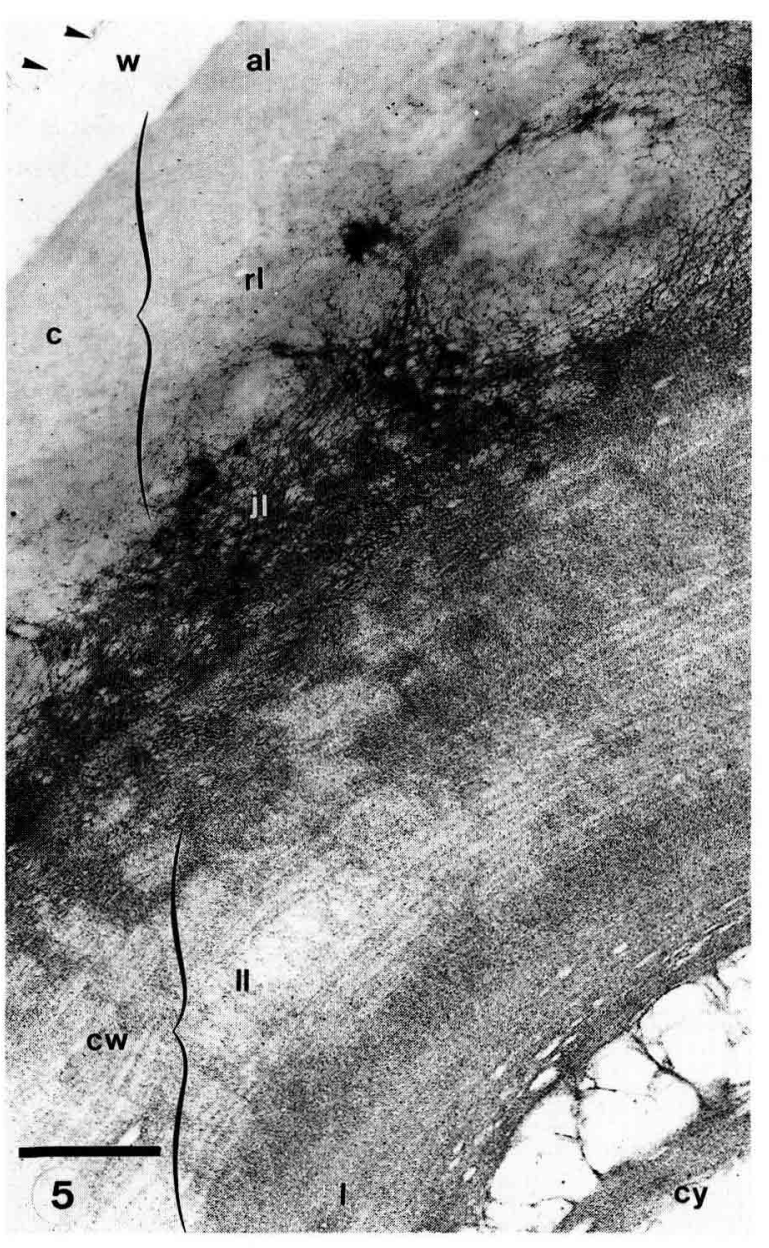

Fig 5. Layering of the outer wall of epidermal cell. The different layers in the wall and in the cuticle of normal epidermis are clearly visible. Note the reticulate structures in the junction layer and the lacunae in the first layer of the wall. The epicuticular waxes are translucent and merely limited by a faintly opaque deposit. al : amorphous layer; c : cuticle; cw : cell wall; cy : cytoplasm; $j l$ : junction layer between wall and cuticle; $r$ : reticulate layer of the cuticle; $w$ : epicuticular waxes; I or II : different layers in the wall; - : surface of the fruit; $-1 \mu \mathrm{m}$.

seems to originate from the cell wall penetrates in the dark matrix. The inner layer of the cuticle (rl) is faintly reticulate but no silver granules can be observed.

Vesicles, strongly contrasted by the PATAg procedure, were usually observed beneath the outer wall of epidermal cells (fig 9). They presented the same lacunary aspect as the inner layer of the wall (I) and were seemingly involved in the secretion of new polysaccharidic components.

\section{Cuticular cracks}

Transverse sections of cuticular cracks could be seen in most of the samples (fig 2). They look superficial and the outer wall of the epidermal cell does not seem to be altered. The junction layer between cuticle and cell wall stretches continuously from one edge of the crack to the other. On the contrary, the outer part of the cuticle is abruptly interrupted. After staining with Sudan red, the inner part of the cuticle and the surface of cracks are stained in orange-red, but the outer part (visible under phase contrast illumination) remains uncoloured (fig 4). It is possible that the cuticle has been partly degraded by the Maxwell reagent, which contains a high concentration of $\mathrm{KOH}$ (Maxwell, 1978).

Under electron microscopic observation, the cell wall located beneath cuticular cracks appears similar to the wall of the epidermal cell covered with normal cuticle and exhibits a succession of 2 layers (fig 10). The edge of the cracks shows an abrupt interruption of the amorphous and reticulate parts of the cuticle, whereas the layer at the junction between wall and cuticle (jl) seemingly covers the wall continuously (fig 11). Moreover, some translucent or faintly opaque material which could be of cuticular origin is frequently observed at the surface of the cracks, covering the dense outer layer of the wall (fig 12).

In any case, many variations occur. The inner part of the epidermal cell wall is not constantly made up of "lacuna-like" regions (fig 13a), either in normal epidermis or in cracks. The outer wall of epidermal cells in cracks is frequently thinner and in those instances, the median layer (II) disappears (fig 13b). It is also important to note that some deeper cracks can be observed at the junction between 2 epidermal cells (fig 14). The adjacent anticlinal walls seem to separate. A dense layer with a reticulate structure is still present at the surface of the wall, but more frequently the junction between epidermal cells in cracks appears "reinforced" by a translucent material which could be of cuticular origin (fig 15).

The layer of epicuticular waxes is not interrupted at the edge of cracks (fig 11) which are more or less covered by waxes (fig 13b). In dewaxed specimens, this translucent layer is never observed (fig 16) at the surface of cracks. 


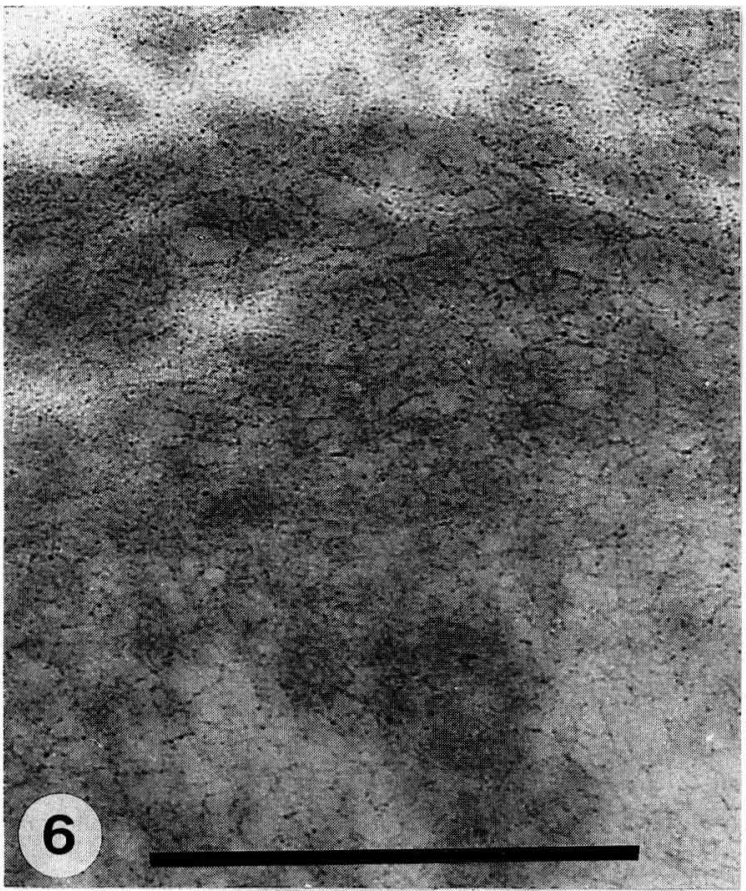

Fig 6. Detail of the reticulate structure at the junction between cell wall and cuticle (il in fig 5). A pattern of granules seems embedded in a dark, amorphous component. Abbreviations as in figure 5 .

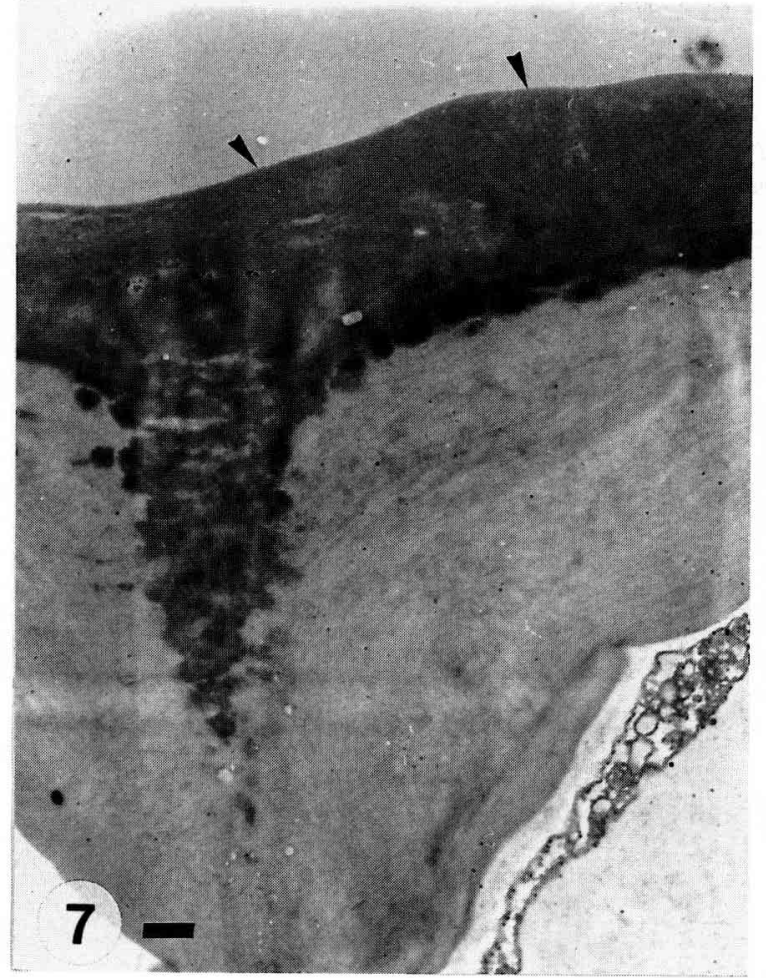

Fig 7. Outer wall of epidermal cell. Specimen dewaxed in chloroform. The layer of cuticular waxes does not appear. Abbreviation as in figure 5 .
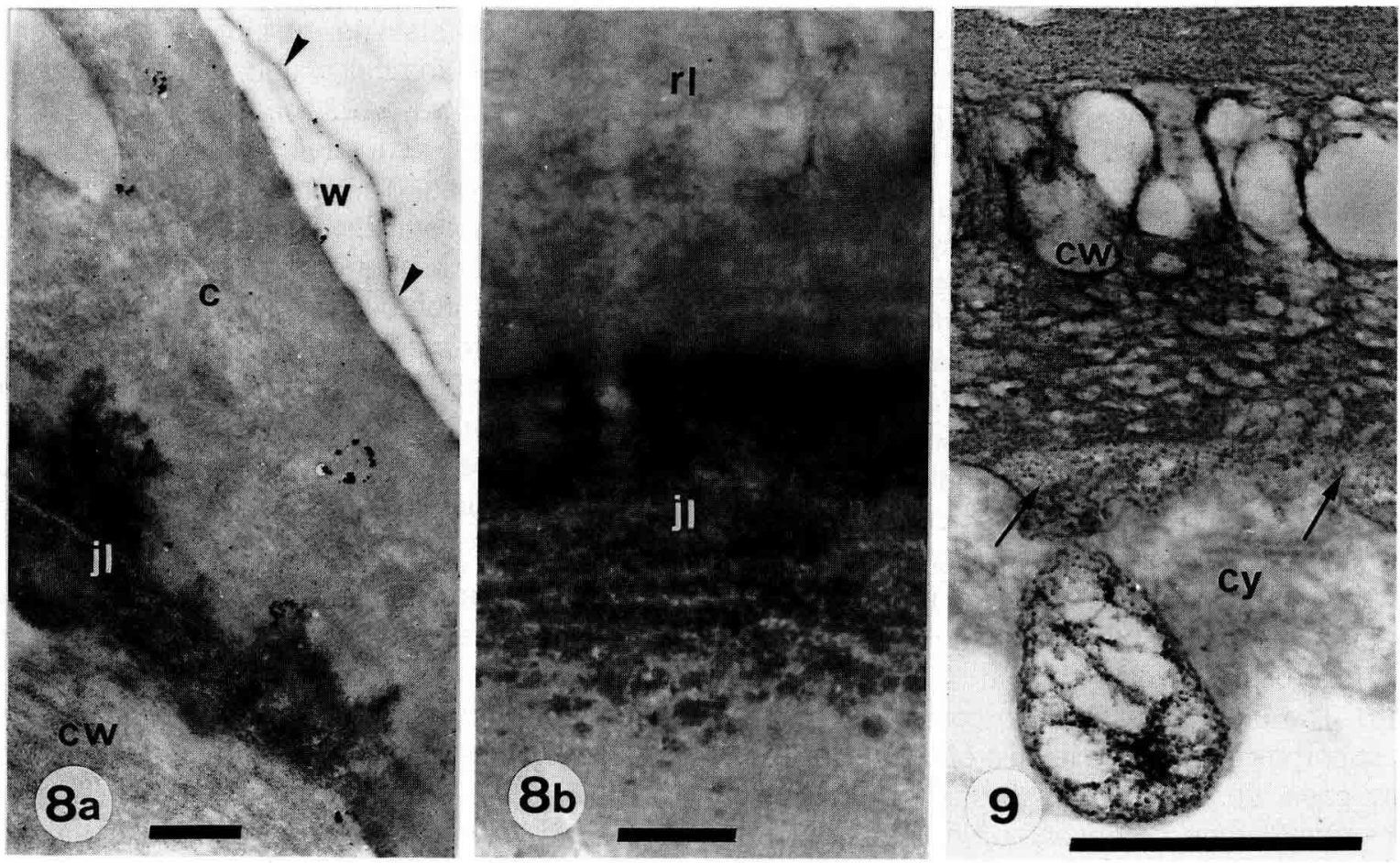

Fig 8. Control of the specificity of the PATAg procedure. Sections were oxidised with $\mathrm{H}_{2} \mathrm{O}_{2}$ instead of periodic acid. The deposit of silver granules in the wall does not appear. The junction layer is opaque (a) but the reticulate pattern of silver granules is absent; (b) compare with figs 5 or 6 . Abbreviations as in figure 1.

Fig 9. Detail of the inner part of the outer wall of an epidermal cell. Note the secretion of polysaccharidic material $(\rightarrow)$ and the "spongy" aspect of the wall. Abbreviations as in figure 5 . 


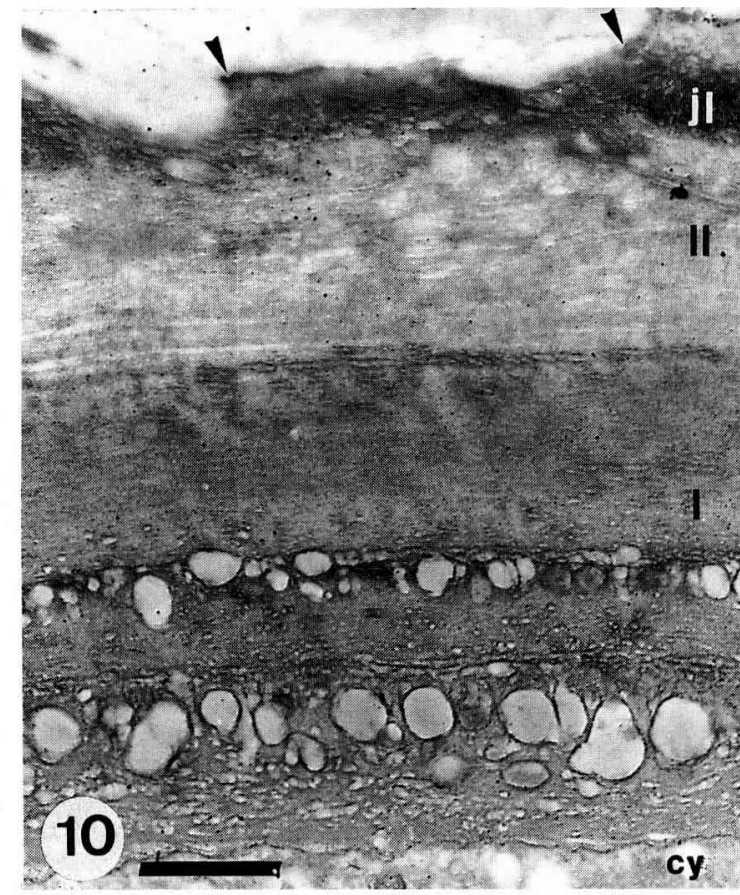

Fig 10. Outer wall of an epidermal cell located in a crack. The wall exhibits the same appearance as in normal epidermis (fig 5). Abbreviations as in figure 5.

\section{Texture of the cell wall}

Methylamine extraction of specimens combined with the PATAg procedure proved to be a useful tool to expose the wall texture (ie the organization of the subunits of the wall) (Reis, 19811982; Roland et al, 1987).

Walls of hypodermal cells show a remanence of a laminated structure disposed symmetrically on both sides of the middle lamella where the structure is strongly disorganized (fig 17). The organization of the outer walls of epidermal cells was more complex. This was similar in cracks and in normal epidermis and exhibited either a compact texture or a disorganized very loose texture. In figure 18 the outer wall consists of 2 layers separated by some "lacuna-like" regions. A laminated architecture is visible in the inner layer (fig 19) with abrupt variations in the orientation of microfibrils, which show a "herring-bone" pattern. The outer layer is more compact with a thick superposition of parallel microfibrils (fig 20). In any case, some variations in the patterns of silver granules can be observed. In figure 21 , a layer of loose, disorganized network of microfibrils is intercalated between 2 more compact layers where some laminated structure can be observed. The outer compact layer is detailed in figure 22. In figure 23 , an extensive disorganization of the wall seems to have dispersed a laminated architecture.

At the surface of cracks, a fibrillar pattern of silver granules seems to be embedded in an amorphous, faintly opaque component (figs 20 , 22). This looks like the prolongation of the junction layers between wall and cuticle (fig 24).

\section{DISCUSSION}

The overall organization of the dermal system of the Tasty-fruit nectarine is similar to that observed by King et al (1987) with other cultivars. The cuticular cracks that we observed are superficial and do not affect the organization of the epidermis.

The structure of the cuticle is consistent with some of the general models reviewed by Holloway (1982). The superposition of an outer amorphous region and an inner reticular one is frequently observed in many plants and organs. Lamellate structures, present in many cuticles (Riederer and Schönherr, 1988) and more especially in the cuticle of grape berries (Rajaei, 1987) was not observed. The purple colour, after toluidine blue staining, of the junction layer between cuticle and cell wall has already been described (Holloway, 1982) and this region is considered to contain both cutin and polysaccharides. The presence of cutin is confirmed by the staining of this layer with Sudan red (fig 4). The blue colour of the cell wall after the colloidal iron-cyanoferrate staining must be caused by free acid groups (Martoja and Martoja-Pierson, 1967), presumably polygalacturonic acid. On the contrary, the yellow colour of the cuticle indicates that acid groups of the fatty acids present in cutin and cuticular waxes are presumably masked.

There is no clear cut between cuticle and cell wall, and the reticulate pattern of the junction layer seems to be the origin of the fibrils which permeate through the cuticle. The junction layer could be the "cutinized wall" layer (Hülsbrusch's model of the cuticle; quoted in Holloway, 1982) and may consist of cutinized polysaccharidic fibrils as previously stated for the reticulate parts of cuticle (Wattendorff and Holloway, 1980, 

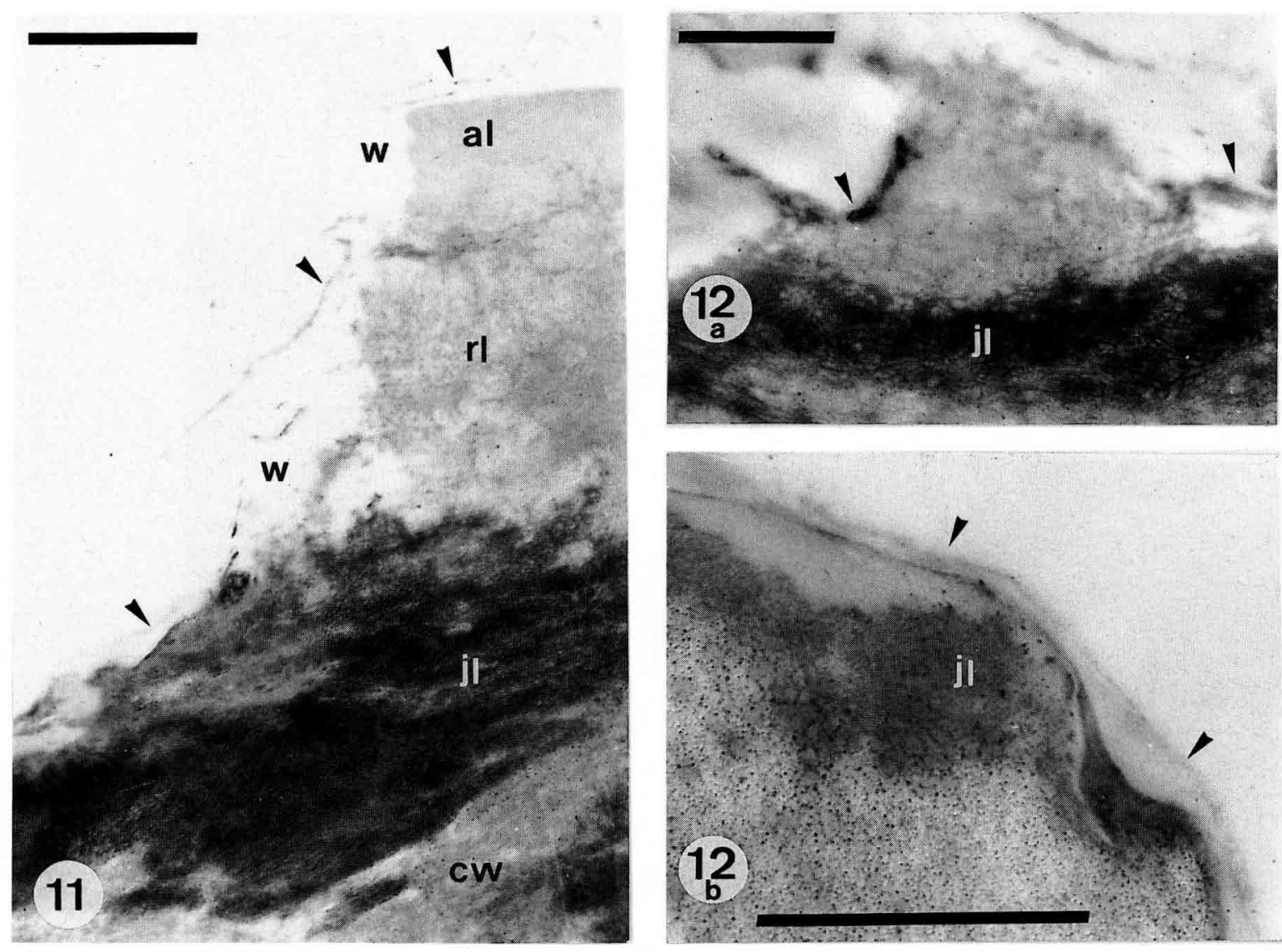

Fig 11. Section of the edge of a cuticular crack (compare with fig 2). The reticulate and amorphous layers of the cuticle are interrupted whereas the epicuticular waxes and the junction layer are continuous.

Fig 12. Various aspects of the surface of a crack. Note the presence of a cuticular residue (a) similar to the reticulate layer in cuticle and of a translucent layer (b) similar to the epicuticular waxes.
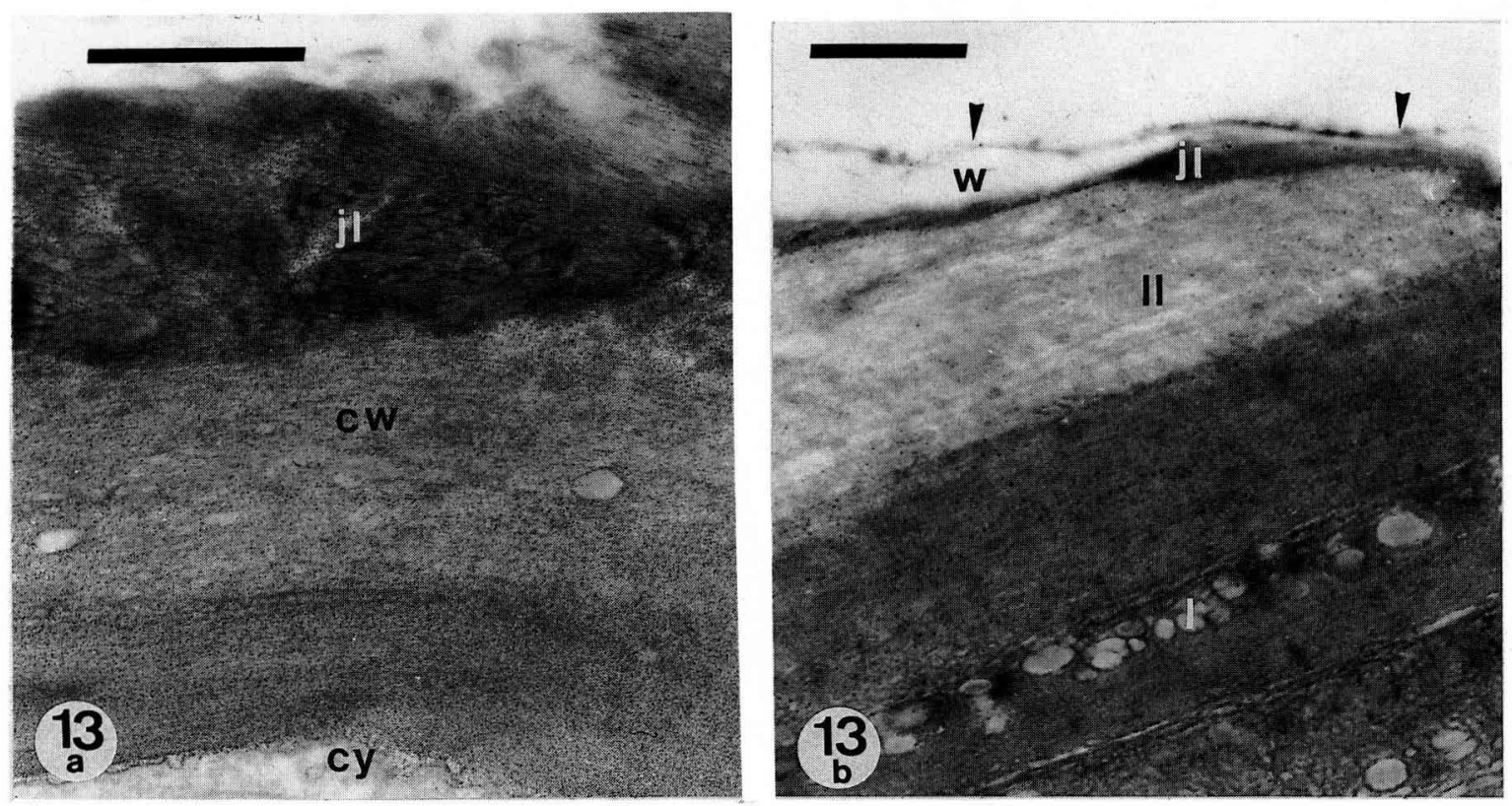

Fig 13. Variations in the structure of the outer wall of an epidermal cell in a crack. Note the absence of lacunae in the first layer of the wall (a) and the vanishing of the median layer (b) the surface of the cracks is presumably covered with waxes in figure $13 \mathrm{~b}$. 


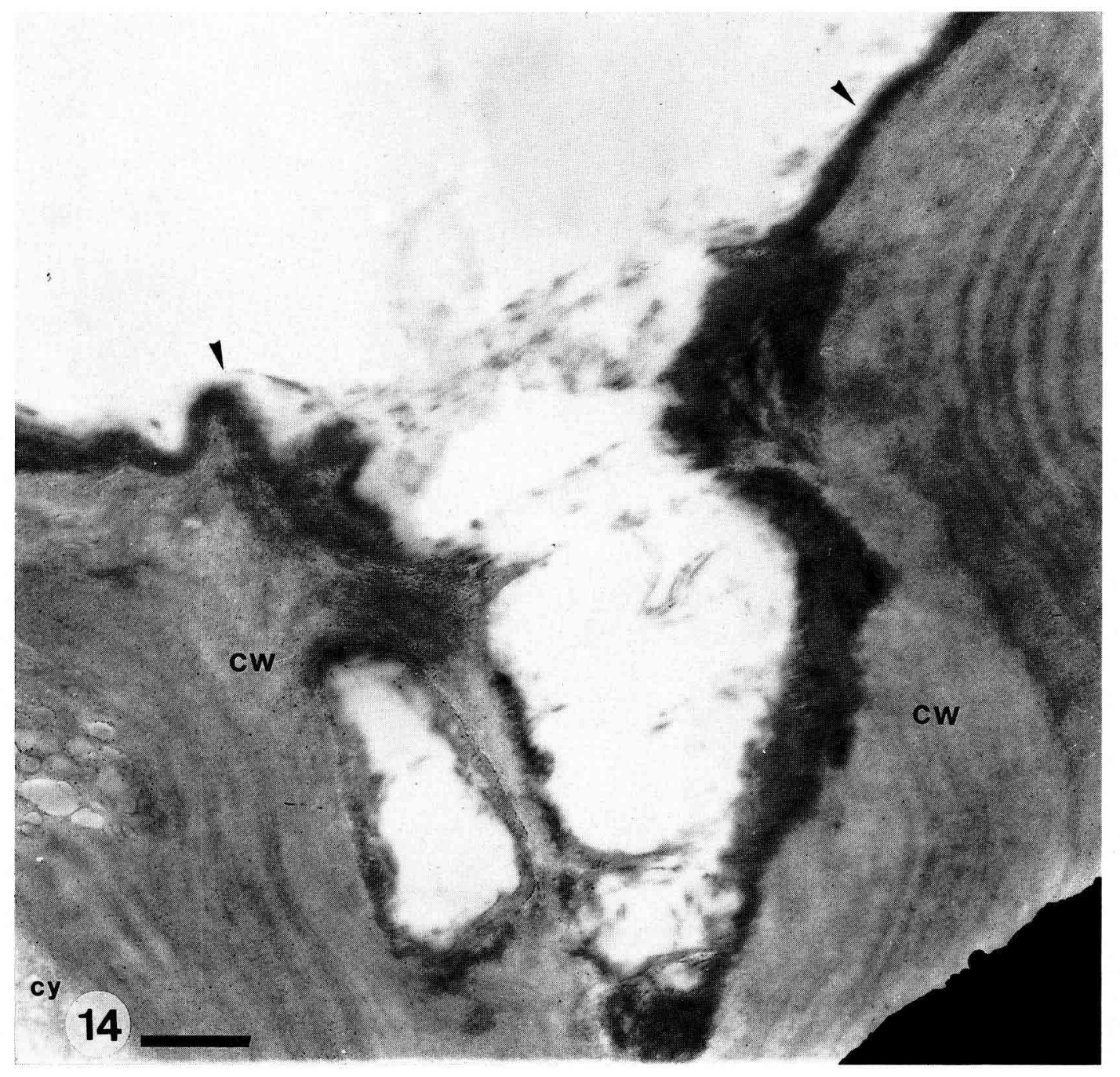

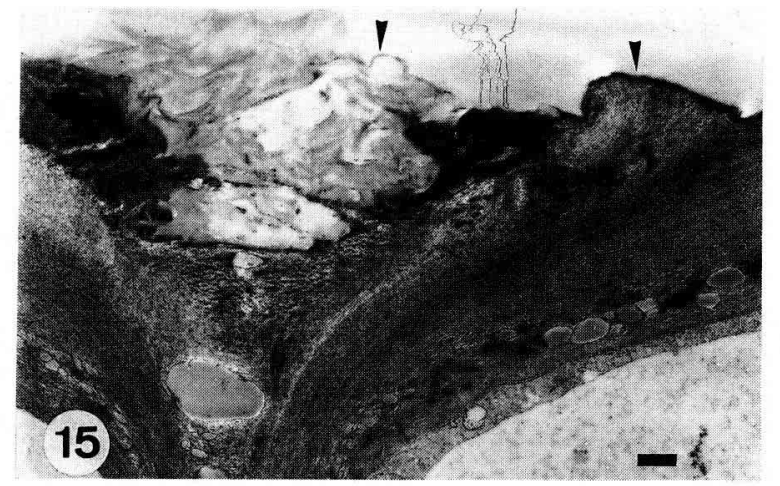

1982). The presence of polysaccharide components at the junction of cuticle and wall is indicated by the fixation of silver granules of the reticulate fibrils in sections contrasted with the PATAg procedure (Thiery, 1967; Roland, 1978). The granules are visible on samples post-fixed with $\mathrm{OsO}_{4}$ and sample not treated with $\mathrm{OsO}_{4}$. Moreover, when $\mathrm{H}_{2} \mathrm{O}_{2}$ is substituted for periodic acid, the reticulate pattern in the junction layer is not visible (fig 8) which confirms their polysaccharide
Figs 14-15. Cracks in anticlinal walls. Abbreviations as in figure 5. Fig 14. Section of a crack which penetrates the anticlinal wall of epidermal cells. Fig 15. Anticlinal wall reinforced by some cuticular material, in a crack.

composition. In the cuticle itself, the deposit of silver granules is faint (fig 5 ) and after oxidation with $\mathrm{H}_{2} \mathrm{O}_{2}$ the fibrils in the reticulate layer ( $\mathrm{rl}$ ) clearly have their own opacity. Similarly, the opacity of the amorphous matrix in the junction layer is not due to the PATAg reaction.

The hypodermal cell wall (fig 17) shows a stratified texture which may consist of the remanence of the helicoidal wall described in Roland et al (1987), disorganised during fruit maturation, 


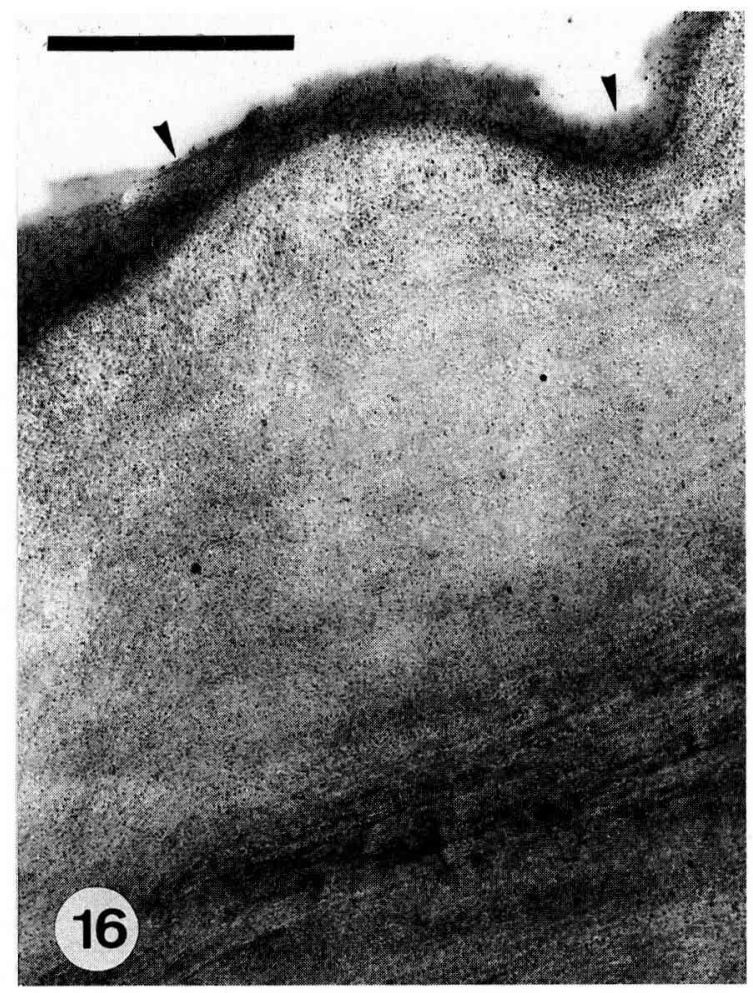

Fig 16. Sections of the outer wall of epidermal cells in a crack. Specimen dewaxed in chloroform. Abbreviations as in figure 5.

as in the case of grapes (Rajaei, 1987). The outer wall of epidermal cells is more complex. Some remanence of the helicoidal wall can be observed, together with some unstratified layers (fig 18). A similar superposition of an inner stratified layer and an outer compact layer was observed by Rajaei (1987) in the epidermis of grapes. The loose and unorganized pattern of microfibrils observed in some regions of the outer wall (fig 21) is probably due to an extensive extraction of this layer by methylamine and is very similar to the middle lamella of hypodermal cell (fig 17). Reis (1981-1982) noted that in samples treated with methylamine, the subcuticular zone was thoroughly extracted. The origin of the very common "lacuna-like" regions in the outer wall remains unexplained. It should be noted that they are always observed in the inner part (ie youngest part) of the wall and that some polysaccharidic material is frequently secreted by the epidermal cell (fig 9). These lacunae are presumably not an artefact of embedding because they are present in samples extracted with methylamine which increased the permeability of the wall.
Moreover, they are solely observed in the outer wall (and sometimes the anticlinal wall) of the epidermal cells. The various aspects observed in the different layers of the outer wall of epidermal cells could be caused both by variations in the patterns of fibrillae deposition and by dispersion of the structure during extension of the cell (Roland et al, 1987; Vian and Roland, 1987). The morphogenesis of the wall beneath the cuticle of nectarine fruit must therefore be rather complex.

The outer wall of epidermal cell in nectarine fruit is thick and exhibits a complex structure which is seemingly not affected by the cracking of the cuticle. The different textures of the layers - stratified with the superposition of fibrillae arranged in varying directions, compacted with parallel fibrillae, unorganized with dispersed fibrillae - may not have the same mechanical strength or the same resistance to biochemical agression. Moreover, the junction layer between wall and cuticle is continuous at the surface of cuticular cracks and the wall is therefore covered with a structure which is probably both polysaccharide and cutin. Some decutinization experiments would be useful to clarify our information. A thin layer of translucent material is frequently present and is removed by a chloroform treatment. Waxes are probably deposited on the surface of cracks.

In respect to the infection of the fruit by fungal pathogen, it should be emphazised that the surface of the cracks is likely to be covered by layers of cutinized polysaccharides and waxes. Although weakened by the absence of reticulated and amorphous cuticle layers, those cracks may therefore not be susceptible to infection. Monilia laxa is an intercellular parasite (Pring et al, 1981) which normally progresses through the middle lamella. The wall of the epidermal cell in cracks which is composed of layers with different fibrillar textures may not allow penetration. Some deeper cracks in the anticlinal wall of some epidermal cells (fig 14) could expose the middle lamella and may provide a better site for the penetration of parasites. This would explain why, on inoculated nectarine observed under a scanning electron microscope, a few cracks only seemed to allow penetration of the fungus (Nguyen-the et al, 1989). In any case, the biochemical composition of cracks should be investigated further together with an ultrastructural study of the infection of nectarine fruit by $M$ laxa and $R$ stolonifer. 

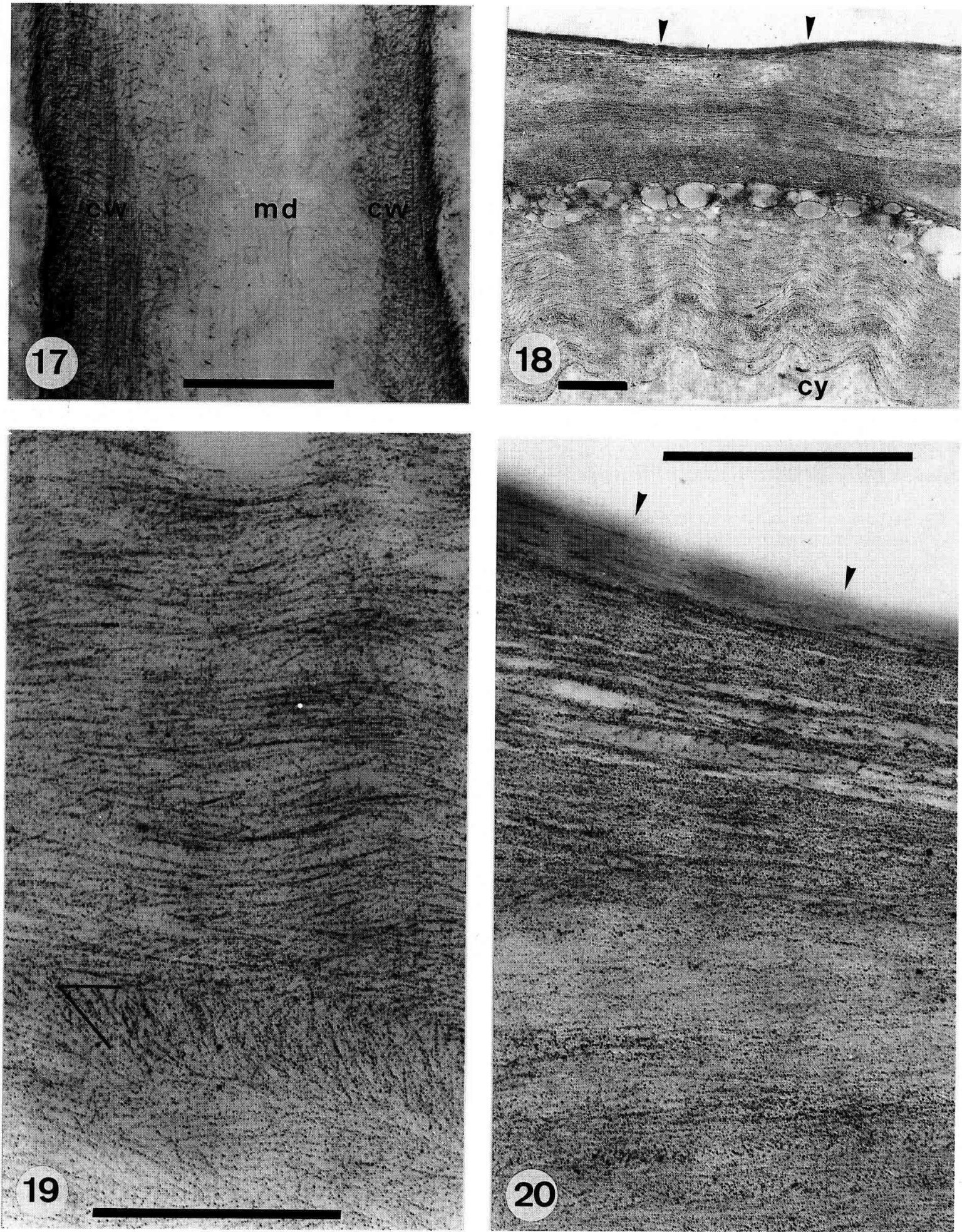

Figs 17-24. Texture of the wall of dermal cells. Specimens extracted with methylamine before embedding. Abbreviations as in figure 5 .

Fig 17. Section of the wall of hypodermal cells.

Figs 18-20. Section of the outer wall of an epidermal cell in a crack. The inner layer is laminated (fig 19) and covered by a more compact layer (detailed in fig 20). Note the "herring-bone" pattern of fibrillae in the inner layer (>). 

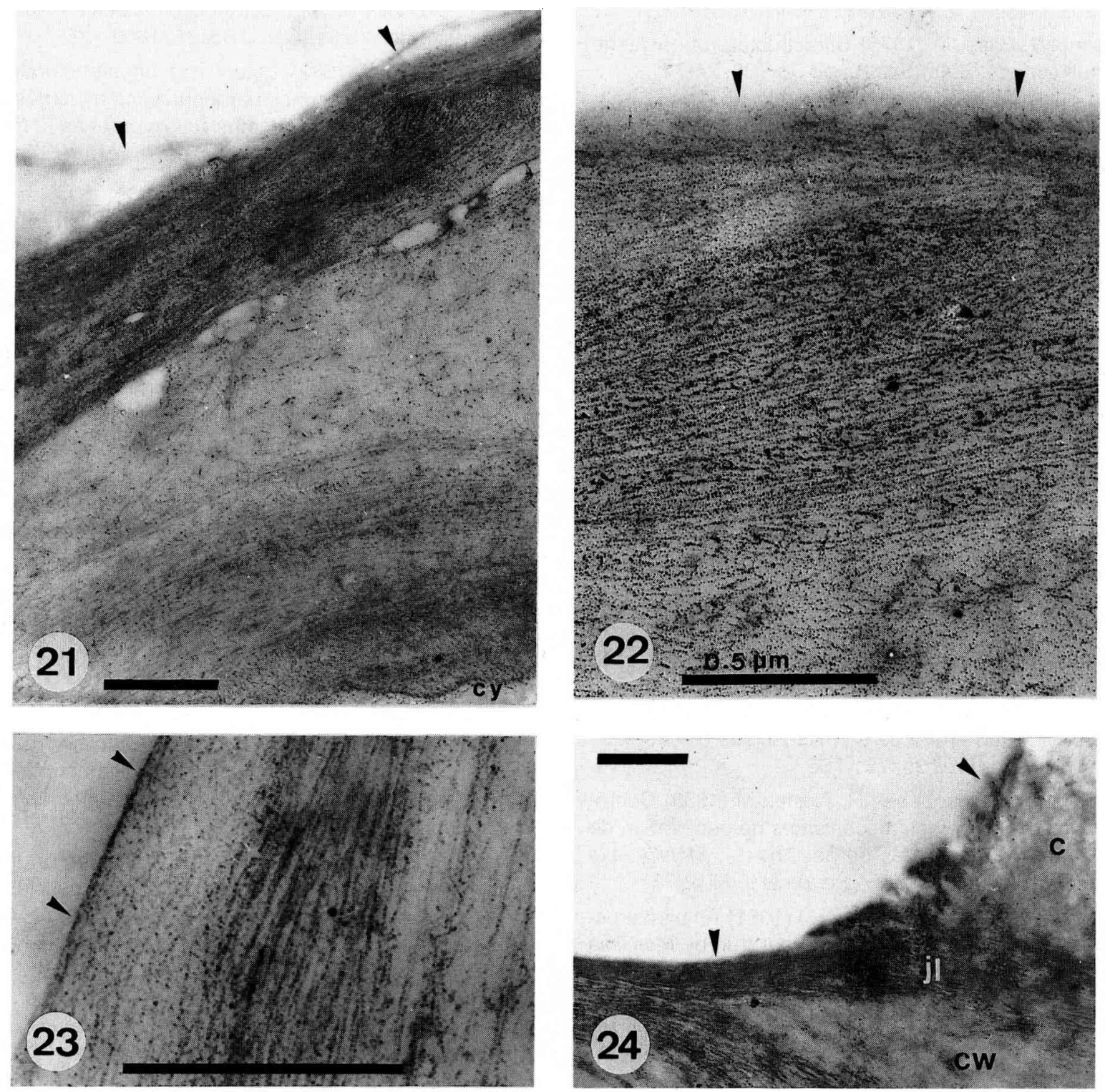

Figs 21-22. Section of the outer wall of an epidermal cell in a crack. Note the presence of a median layer with a loose and disorganized pattern of fibrillae and a compact outer layer (detailed in fig 22).

Fig 23. Surface of a crack, the wall of which exhibit a very loose structure.

Fig 24. Section of the edge of a crack which shows the continuity of the junction layer.

\section{ACKNOWLEDGMENTS}

This work was supported by a grant from the Institut National de la Recherche Agronomique (France) and was performed in the Laboratoire des Biomembranes et Surfaces Cellulaires Végétales at the École Normale Supérieure (Paris, France), with the assistance of $\mathrm{B}$ Vian and $\mathrm{JC}$ Roland.

\section{REFERENCES}

Bessis R (1972) Étude de l'évolution des stomates et des tissus péristomatiques du fruit de la vigne. $C R$ Seances Acad Sci (Paris) Sér D 274, 2158-2161

Dean BB, Kolattukudy PE (1976) Synthesis of suberin during wound-healing in jade-leaves, tomato fruit, and bean pods. Plant Physiol 58, 411-416 
Fleuriet A, Deloire A (1982) Aspects histochimiques et biochimiques de la cicatrisation des fruits de tomate blessés. Z Pflanzenphysiol 107, 259-268

Fogle HW, Faust M (1975) Ultrastructure of nectarine fruit surface. J Am Soc Hortic Sci 100, 74-77

Fogle HW, Faust M (1976) Fruit growth and cracking in nectarines. J Am Soc Hortic Sci 101, 434-438

Holloway PJ (1982) Structure and histochemistry of plant cuticular membranes: an overview. In: The Plant Cuticle (Cutler DF, Alvin KL, Price DE, eds) Acad Press, London, 1-32

King GA, Henderson KG, Ross EL (1987) Growth and anatomical and ultrastructural studies of nectarine fruit wall development. Bot Gaz 148, 443-455

Kolattukudy PE, Koller W (1983) The fungal penetration of the first line defensive barriers of plants. In: Biochemical Plant Pathology (Callow JA, ed) John Wiley Sons, Chichester, 79-100

Martoja R, Martoja-Pierson M (1967) Initiation aux Techniques de l'Histologie Animale. Masson, Paris, $345 \mathrm{pp}$

Maxwell MH (1978) Two rapid and simple methods used for the removal of resins from 1.0- $\mu \mathrm{m}$ thick epoxy sections. J Microsc 112, 253-255

Mourichon X, Bompeix G (1970) Mise en évidence des voies de pénétration du Phytophtora cactorum ( $L$ et $C$ ) Schroeter dans les pommes "Golden delicious». Étude réalisée en microscopie électronique à balayage. Fruit 34, 761-766

Nguyen-the C, Hugueney R, Arnoux M (1989) Contribution à l'étude des mécanismes de pénétration de 2 parasites fongiques de nectarines: Monilia laxa et Rhizopus stolonifer. Agronomie 9, 271-276

Pring RJ, Byrde RJW, Willetts HJ (1981) An ultrastructural study of the infection of pear fruit by Monilinia fructigena. Physiol Plant Pathol 19, 1-6
Rajei H (1987) Changements cytochimiques et ultrastructuraux des parois cellulaires de la pellicule du raisin, Vitis vinifera, durant la croissance et la maturation de la baie. Can J Bot 65, 1343-1355

Reis D (1981-1982) Cytochimie ultrastructurale des parois en croissance par extractions ménagées. Effets comparés du diméthylsulfoxyde et de la méthylamine sur la démasquage de la texture. Ann Sci Nat Bot (Paris) 2-3, 121-136

Riederer M, Schönherr J (1988) Development of plant cuticles: fine structure and cutine composition of Clivia minata Reg leaves. Plant 174, 127-138

Roland JC (1978) General preparation and staining of thin sections. In: Electron microscopy and Cytochemistry of Plant Cells (Hall JL, ed) Elsevier North Holland Biochemical Press, NewYork, 1-62

Roland JC, Reis D, Vian B, Satiat-Jeunemaitre B, Mosiniak M (1987) Morphogenesis of plant cell walls at the supramolecular level: internal geometry and versatility of helicoidal expression. Protoplasma $140,75-91$

Thiery JP (1967) Mise en évidence des polysaccharides sur coupes fines en microscopie électronique. J Microsc 6, 987-1017

Vian B, Roland JC (1987) The helicoidal cell wall as a time register. New Phytol 105, 345-357

Wattendorff J, Holloway PJ (1980) Studies on the ultrastructure and histochemistry of plant cuticles: the cuticular membrane of Agave americana $L$ in situ. Ann Bot (Lond) 46, 13-28

Wattendorff J, Holloway PJ (1982) Studies on the ultrastructure and histochemistry of plant cuticles: isolated cuticular membrane preparations of Agave americana $L$ and the effects of various extraction procedures. Ann Bot (Lond) 49, 769-804 